\title{
Mitochondrial Diabetes A Rare Case
}

\author{
Singh AK ${ }^{1}$, Aoki $\mathrm{M}^{2}$, Miyata $\mathrm{M}^{3}$, Mine $\mathrm{Y}^{4}$, Suzuki J5, Urakami ${ }^{6}$
}

\begin{abstract}
A 25 years female diagnosed and confirmed mitochondrial by gene analysis mutation DNA 3243(A-G). CQ10 was useful for the resolution of clinical symptoms, and metformin should be avoided in mito-chondrial diabetes.
\end{abstract}

Key words: Mitochondrial diabetes, Metformin, WolffParkinson-White (WPW) syndrome.

\section{Introduction}

M itochondrial diabetes first described in 1992 by van den Ouweland et al in a Dutch family and by Reardon et al in a UK family ${ }^{1}$ mitochondrial diabetes is commonly associated with sensorineural deafness and is characterised by progressive nonautoimmune beta-cell failure ${ }^{2}$. Maternal transmission of mutated mitochondrial DNA (mt DNA) can result in maternally inherited diabetes. Although several mutations have been implicated, the strongest evidence relates to a point substitution at nucleotide position 3243 ( $A$ to $G$ ) in the mitochondrial tRNA [leu(UUR)] gene ${ }^{3}$. Besides the frequently reported $m t D N A 3243 A>G$ mutation ${ }^{4}$, several other mtDNA variants have been associated with a diabetic phenotype suggestive of MIDD ${ }^{5,6}$. Characteristics of mitochondrial diabetes mellitus (MDM) presenting with the mitochondrial DNA $3243(A \rightarrow G)$ mutation are short stature, slim body type, neurosensory deafness, cardiomyopathy, and central nervous disorder 6 .

Currently, there is no effective therapy for treating MDM. In this study, we reviewed a case of MDM presenting with the mitochondrial DNA $3243(A \rightarrow G)$ mutation, and CQ10 was useful for the resolution of its characteristic clinical symptoms ${ }^{7}$.

\section{The Case}

Twenty five years old female was detected as having glycosuria conducted at her school and referred to Nihon University, Tokyo, Japan about 15 years ago she was not obese and negative for all pancreatic antibodies, her $\mathrm{HbA} 1 \mathrm{c}$ was $9.7 \%$ and insulin secretion was not exhausted. After eight months since regular visit, she was diagnosed as having MDM presenting with mitochondrial DNA 3243 (A-G) mutation. She had taken oral hypoglycaemic agents and received insulin injections, and HBA1c level was $8 \%-9 \%$. Electrocardiogram was done 12 years back where she was diagnosed with WolffParkinson-White (WPW) syndrome.
${ }^{1}$ Dr. Arun Kumar Singh, MBBS, MD, FellowshipPaediatric Endocrinology and Diabetes, BP Koirala Institute of Health Sciences, Dharan, Nepal, ${ }^{2}$ Dr. Aoki Msasko, ${ }^{3} \mathrm{Dr}$. Midori Miyata, ${ }^{4} \mathrm{Dr}$. Yusuke Mine, ${ }^{5} \mathrm{Dr}$. Junichi Suzuki, ${ }^{6}$ Dr. Tatsuhiko Urakami, all from the Department of Paediatrics, Nihon University Hospital,Tokyo,Japan.

\section{Address for correspondence \\ Dr. Arun Kumar Singh \\ E-mail; arunsinghnepal@gmail.com}

\section{How to cite}

Singh AK, Aoki M, Miyata M, Mine Y, Suzuki J, Urakami T. Mitochondrial Diabetes A Rare Case. J Nepal Paediatr Soc 2017;37(3):290292.

doi:http://dx.doi.org/10.3126/jnps.v37i3.18765

This work is licensed under a Creative Commons Attribution 3.0 License. 
At one year of age left ventricular hypertrophy was detected and diagnosed with mitochondrial cardiomyopathy. Bilateral sensory deafness was identified at the age of sixteen. Growth developmental history was normal.

Her mother is now 43 years old and is diabetes patient with hypoglycaemic agent. At 33 years of age her mother was diagnosed with 3243 mutation and her father is not diabetic. She has one sister who was also diagnosed as 3243 mutation at age of 13 years.

During her stay in the hospital her laboratory findings recorded were, $\mathrm{HbA} 1 \mathrm{c}: 10.3 \%$, Lactate: $28.8 \mathrm{mg} / \mathrm{dL}$, Pyruvic acid: $1.45 \mathrm{mg} / \mathrm{dL}$, Lactate/Pyruvic acid ratio: 19.9 , TSH: $0.41 \mu \mathrm{IU} / \mathrm{mL}$, T3: $2.36 \mathrm{pg} / \mathrm{mL}$, T4: $0.98 \mathrm{ng} / \mathrm{dL}, \mathrm{GAD}$ antibody $:<5.0 \mathrm{U} / \mathrm{mL}$, IA-2 antibody: $<0.4 \mathrm{U} / \mathrm{mL}$, Peripheral nerve conduction velocity; Median nerve: $31.4 \mathrm{~m} / \mathrm{s}$, peroneal nerve: $14.9 \mathrm{~m} / \mathrm{s}$.

\section{Discussion}

Patient was diagnosed and confirmed mitochondrial diabetes by gene analysis mutation DNA 3243 (A-G) Metformin should be avoided in Mitochondrial diabetes ${ }^{9}$, because risk of severe lactic acidosis in presence of mitochondrial dysfunction ${ }^{6}$. So on should need to properly investigate and diagnose diabetes patients for better treatment and management in developing country ${ }^{8}$. Other form of insulin dependent DM associated

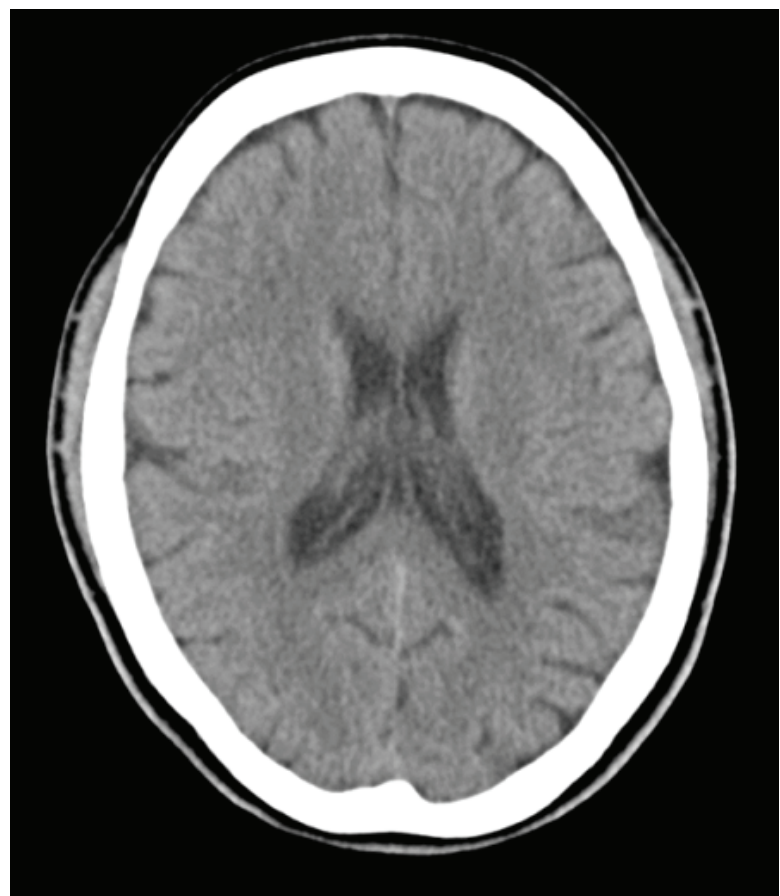

Fig 1: CT scan showing bilateral cortical sulci and ventricular systems are mildly prominent- suggestive of mild cerebral atrophy, bilateral cerebral hemisphere are normal. No calcification. No extra axial collection.

with mitochondrial mutation is WPW syndrome. For the resolution of MDM symptoms free at least one month of CQ10 should be prescribed ${ }^{9}$.

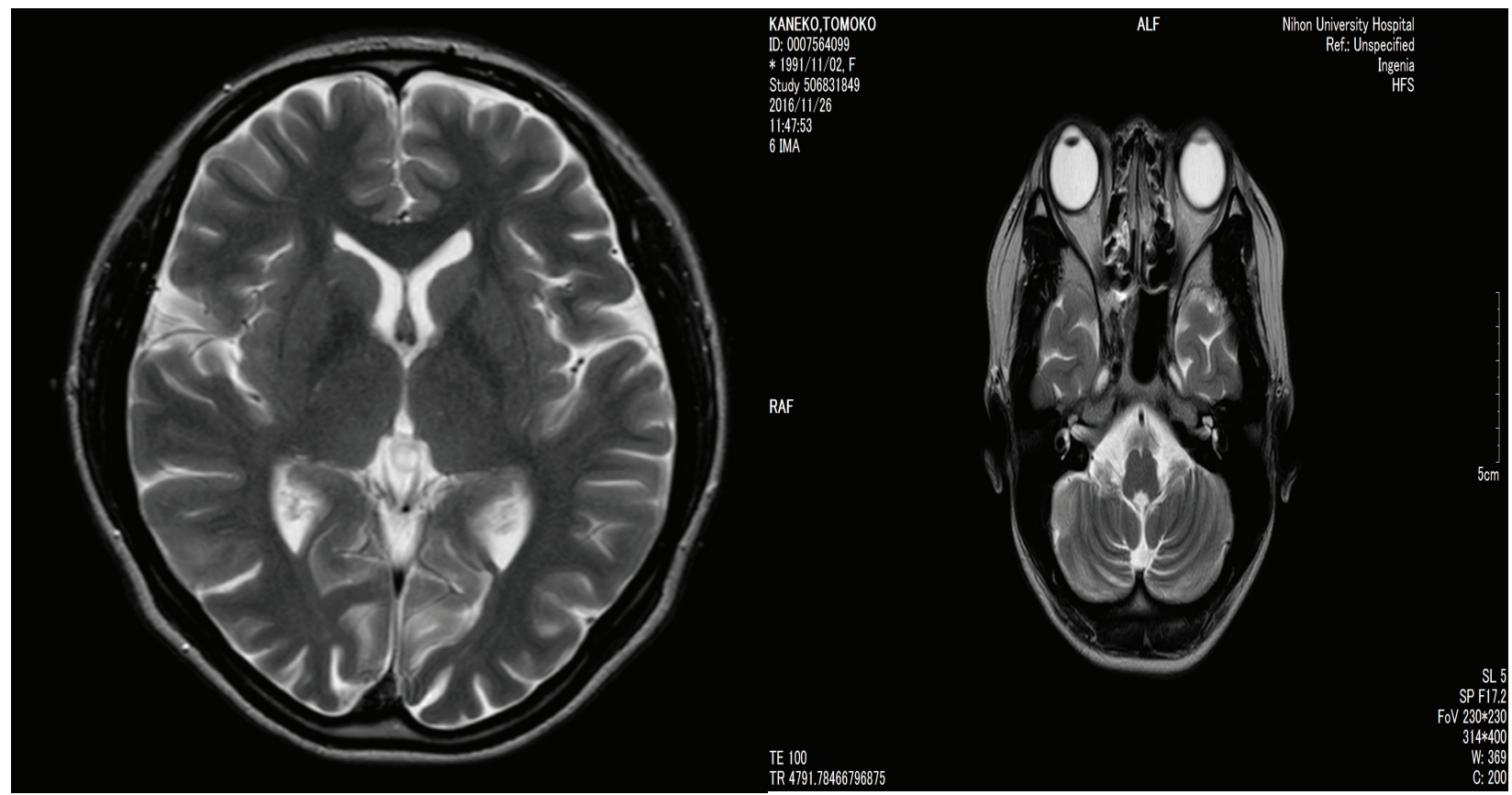

Fig 2: Shows bilateral cortical sulci, ventricular system and CSF spaces in posterior fossa are prominent-suggestive of diffuse brain atrophy. Bilateral cerebral hemisphere are normal in signal intensity 


\section{Conclusion}

Beside CQ10 multiple daily insulin injections started, so it was difficult to understand which of the two resulted in resolution of the symptoms; however, insulin secretion improved and $\mathrm{HbA} 1 \mathrm{c}$ level and lactic acid was decreased. CQ10 was considered effective for MDM. In this regard, further evaluation needed to elucidate the effect of CQ10 and Metformin should be avoided in mitochondrial diabetes

\section{References}

1. Van den Ouweland JM1, Lemkes HH, Ruitenbeek W, Sandkuijl LA, de Vijlder MF, Struyvenberg PA, et al. Mutation in mitochondrial tRNA(Leu)(UUR) gene in a large pedigree with maternally transmitted type II diabetes mellitus and deafness. Nat Genet 1992. 1(5): p. 368-71. DOI: $10.1038 / n g 0892-368$

2. Reardon $W$, Ross RJ, Sweeney MG, Luxon LM, Pembrey ME, Harding AE, et al. Diabetes mellitus associated with a pathogenic point mutation in mitochondrial DNA. Lancet 1992:340:1376-379. DOI: $10.1159 / 000127415$

3. J. Antonie Maassen, Leen. M. 't Hart, Einar van Essen, Rob J. Heine, Giel Nijpels, Roshan S. Jahangir Tafrechi, Anton K. Raap, George M.C. Janssen, Herman H.P.J. Lemkes. Diabetes 2004;53(suppl 1):S103-S109. DOI: 10.2337/diabetes.53.2007.S103

4. Maechler P, Wollheim CB. Mitochondrial function in normal and diabetic beta-cells. Nature 2001;414(6865):807-12. DOI: 10.1038/414807a.

5. Crispim D, Estivalet AA, Roisenberg I, Gross JL, Canani LH. Prevalence of 15 mitochondrial DNA mutations among type 2 diabetic patients with or without clinical characteristics of maternally inherited diabetes and deafness. Arq Bras Endocrinol Metab
2008;52:1228-235. DOI: http://dx.doi.org/10.1590/ S0004-27302008000800005.

6. Mariotti C, Tiranti V, Carrara F, Dallapiccola B, DiDonato S, Zeviani M. Defective respiratory capacity and mitochondrial protein synthesis in transformant cybrids harboring the IRNA(Leu(UUR)) mutation associated with maternally inherited myopathy and cardiomyopathy. J Clin Invest 1994;93:1102-107. DOI: 10.1172/JCl117061

7. Malfatti E, Bugiani M, Invernizzi F, de Souza CF, Farina L, Carrara F, et al. Novel mutations of ND genes in complex I deficiency associated with mitochondrial encephalopathy. Brain 2007;130:1894-1904. DOI: https://doi.org/10.1371/journal.pone.0034956

8. Ushijima K, Fukami M, Ayabe T,Narumi S, Okuno M, Nakamura A, et al. The Japanese Study Group of Insulin Therapy for Childhood Ado-lescent Diabetes. Comprehensive screening for monogenic diabetes in 89 Japanese children with insulin-requiringantibodynegative type 1 diabetes. Pediatr Diabetes 2017;0:1-8. DOI: 10.1111/pedi.12544

9. Suzuki S, Hinokio Y, Ohtomo M, Hirai M, Hirai A, Chiba $M$, et. al. The effects of coenzyme Q10 treatment on maternally inherited diabetes mellitus and deafness, and mitochondrial DNA 3243 (A to G) mutation. Diabetologia 1998;41(5):584-8. DOI: https://doi. org/10.1007/s001250050950. 